\title{
TEATER DAN PUSAT INFORMASI WISATA
}

\author{
Marisha Nelwan ${ }^{1)}$, Mieke Choandi ${ }^{2)}$ \\ ${ }^{1)}$ Program Studi S1 Arsitektur, Fakultas Teknik, Universitas Tarumanagara, marishanelwan@gmail.com \\ ${ }^{2)}$ Program Studi S1 Arsitektur, Fakultas Teknik, Universitas Tarumanagara, miekec@ft.untar.ac.id
}

\begin{abstract}
Abstrak
Jakarta sebagai Ibukota Negara Indonesia dan dapat pula menjadi destinasi wisata bagi turis lokal maupun interlokal. Tempat wisata yang paling diminati oleh turis adalah kota tua. Kota tua memiliki sejarah yang menarik dan bangunan-bangunan tua yang indah. Oleh karena itu Mentri Pariwisata menjadikan kota tua sebagiai pusat wisata bagi kota Jakarta. Untuk menunjang program ini diharapkan tidak hanya terjadi di kota Jakarta saja mengingat Indonesia berupa Negara maritim yang memiliki kawasan-kawasan wisata yang menarik sebagi defisa negara. Untuk itu mendirikan suatu proyek yang menyajikan pertunjukan secara visual dan pengetahuan dalam galeri serta beraneka ragam kuliner dan aksesoris. Untuk mencapai tujuan, maka dirikan sebuah proyek teater dan pusat informasi wisata di kota tua, yang diharapkan memudahkan turis-turis untuk memperoleh informasi secara luas.
\end{abstract}

Kata Kunci: kuliner, pertunjukan, seni, wisata

\begin{abstract}
Jakarta as the Capital of Indonesia and also can be a tourist destination for local and longdistance tourists. The most popular tourist spot is the old city. The old city has an interesting history and beautiful old buildings. Therefore the Minister of Tourism makes the old city a tourist center for the city of Jakarta. To support this program, it is hoped that it will not only occur in the city of Jakarta, considering that Indonesia is a maritime country that has attractive tourist areas. For this reason, establishing a project that presents visual and knowledge shows in galleries and a variety of culinary and accessories. To reach the purpose, a theater and tourist information center project is established in the old city, which is expected to make it easier for tourists to get information widely.
\end{abstract}

Keyword: art, culinary, performances, tourism

\section{PENDAhULUAN \\ Latar Belakang}

Jakarta sebagai ibukota Negara Indonesia, menjadi salah satu tempat tujuan wisata yang paling diminati turis. Jakarta memiliki beberapa destinasi wisata. Salah satu destinasi wisata yang sering dikunjungi turis mancanegara dan lokal adalah kota tua. Kota tua menjadi destinasi wisata bangunan bersejarah di Jakarta. Keindahan bangunan tua yang berada di kota tua memiliki nilai sejarah yang menceritakan mengenai masa lalu dari kota tua. Kota tua yang dulunya menjadi pusat perdangangan sekarang menjadi pusat wisata bangunan bersejarah di Jakarta. Dalam data statistik pengunjung wista kota tua dari tahun 2001-2010 terjadi kenaikan dan penurunan jumlah turis di kota tua yang cukup signifikan pertahunnya dalam rentang $-13 \%$ sampai dengan $+8 \%$.

Banyaknya turis yang mengunjungi kota tua dapat menambah potrensi kota tua untuk menjadi pusat wisata, bukan saja wisata bersejarah tetapi juga beberapa wisata kuliner, dan aneka ragam seni. Yang dirasakan kurang adalah pusat informasi mengenai tempat-tempat wisata yang ada di Indonesia serta yang mampu memberikan ruang, bagi para senimanan baik dari dalam kota Jakarta maupun dari luar kota Jakarta untuk mengekspresikan kebudayaan daerahnya, serta anekaragam kuliner dan souvenir masing-masing daerah di Indonesia yang sudah ada di kota tua kuliner setempat saja. budaya dan kerajinan yang dihasilkan. 
Tabel 1. Statistik Pengunjung Kota Tua

\begin{tabular}{|r|r|r|l|}
\hline \multicolumn{1}{|c|}{ Tahun } & \multicolumn{1}{|c|}{ Jumlah } & \multicolumn{1}{|c|}{ Growth } & Satuan \\
\hline 2001 & 9090923 & 1.86 & Persen \\
\hline 2002 & 9108728 & 0.2 & Persen \\
\hline 2003 & 9088420 & -0.22 & Persen \\
\hline 2004 & 13577000 & 49.39 & Persen \\
\hline 2005 & 11746250 & -13.48 & Persen \\
\hline 2006 & 12777571 & 8.78 & Persen \\
\hline 2007 & 14055328 & 10 & Persen \\
\hline 2008 & 15741967 & 12 & Persen \\
\hline 2009 & 16708834 & 6.14 & Persen \\
\hline 2010 & 18045541 & 8 & Persen \\
\hline
\end{tabular}

Sumber: http://data.jakarta.go.id/dataset/data-kunjungan-wisatawan-nusantara-dki-jakarta

\section{Teori Pendukung}

Bernard Beckerman, kepala departemen drama di Univesitas Hofstra, New York, dalam bukunya Dynamics of Drama, mendefinisikan teater sebagai tempat seorang manusia atau lebih, melakukan aktifitas dalam suatu waktu/ ruang, menghadirkan diri mereka pada orang lain.

Menurut Kamus Besar Bahasa Indonesia, teater adalah:

- Gedung atau ruangan tempat pertunjukan film, sandiwara, dan sebagainya

- Ruangan besar dengan deretan kursi-kursi ke samping dan ke belakang untuk mengikuti kuliah atau untuk peragaan ilmiah

- Pementasan drama sebagai suatu seni atau profesi; seni drama; sandiwara; drama

Menurut Poerwadarminanta (1976:303), gedung berarti bangunan (rumah) untuk kantor, rapat/atau tempat mempertunjukkan hasil-hasil kesenian.Sedangkan pertunjukan adalah tontonan(seperti bioskop, wayang, wayang orang $\mathrm{dsb}$ ). Jadi, gedung pertunjukan merupakan suatu tempat yang digunakan untuk mempergelarkan pertunjukan, baik itu bioskop, wayang, pagelaran musik maupun tari.

Menurut Aska Savoy(2017), fungsi dari sebuah teater berbanding lurus dengan pertunjukan yang ditampilkan, namun seiring berkembangnya jaman dan teknologi, sudah banyak gedung teater yang multi-fungsi, seperti ballroom dengan fungsi sebagai dance hall, music concert, public performing space dengan fungsi sebagai pementasan drama. Menurut Ham(1987), teater juga dapat diklasifikasikan menurut kapasitas penonton yang ditampungnya.

- Sangat besar yaitu teater yang memiliki 1500 kursi penonton atau lebih.

- Besar yaitu teater yang memiliki 900 - 1500 kursi penonton.

- Sedang yaitu teater yang memiliki 500-900 kursi penonton.

- Kecil yaitu Teater yang memiliki kurang dari 500 kursi penonton.

\section{METODE PERANCANGAN}

Metode yang digunakan dalam pembahasan adalah metode analisa deskriptif dengan menyajikan data yang dianggap relevansi dengan permasalahan dan persoalan yang ada, baik yang diperoleh dari survey, studi literature, internet maupn pengalaman untuk kemudian dianalisa dan disimpulkan guna dijadikan dasar penyusunan konsep perencanaan dan perancangan Teater dan Pusat Informasi Wisata. 


\section{HASIL DAN PEMBAHASAN}

\section{Letak Kota Tua}

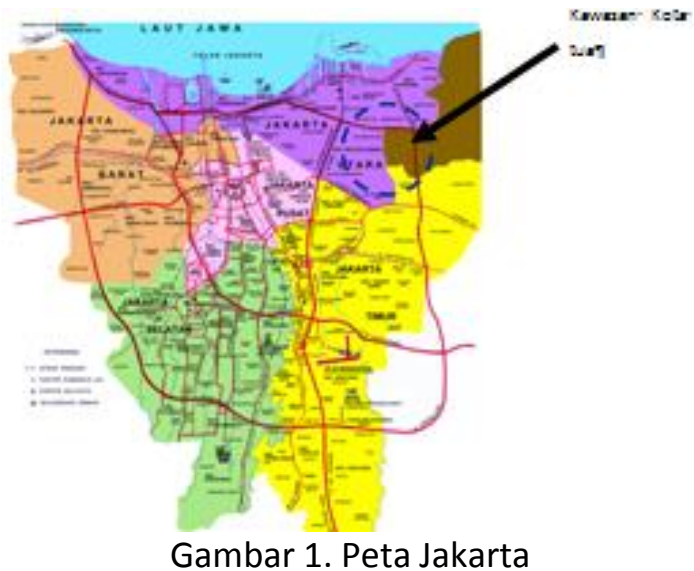

Sumber : https://www.google.co.id/search?q=peta+jakarta\&rlz

Kota tua dikenal sebagai Batavia Lama( Old Batavia), merupakan sebuah wilayah kecil di Jakarta baian Utara yang memiliki luas $1.3 \mathrm{~km} 2$ melintasi Jakarta Utara dan Jakarta barat. Pada abad ke-16 tempat ini di juluki Permata Asia dan Ratu dari timur oleh pelayar dari Eropa, karena dianggap sebagai pusat perdagangan untuk benua Asia serta letaknya disepanjang pesisir laut yang lokasinya strategis dan sumber daya yang melimpah.

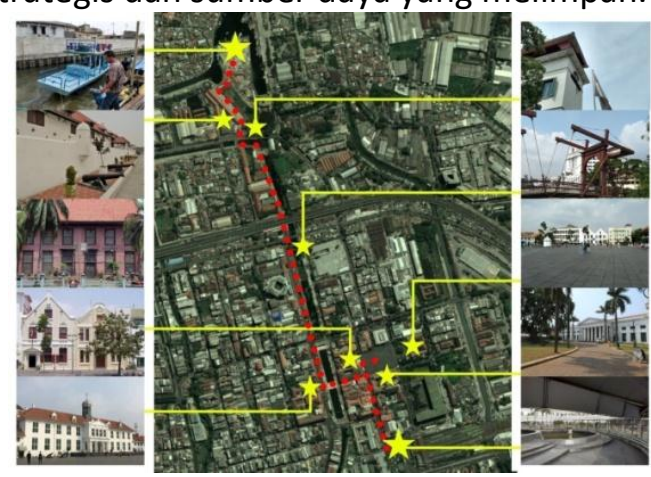

Gambar 2. Peta Jalur dari Museum Fatahilah hingga Museum Bahari(Kampung Aquarium) Sumber : Data Pribadi

Dari peta di atas dapat dilihat kawasan wisata kota tua berada dari stasiun kota Jakarta hingga Museum yang belum terbentuk secara nyata. Sehingga hingga saat ini para wisatawan hanya berkeliling di sekitar kawasan Museum Fatahilah tanpa tahu adanya bangunan bersejarah lainya yang tidak kalah menarik. Menelusuri jalur yang sudah terbentuk dapat membantu para turis untuk berjalan menusuri kota tua dengan destinasi yang ada.

\section{Trasportasi}

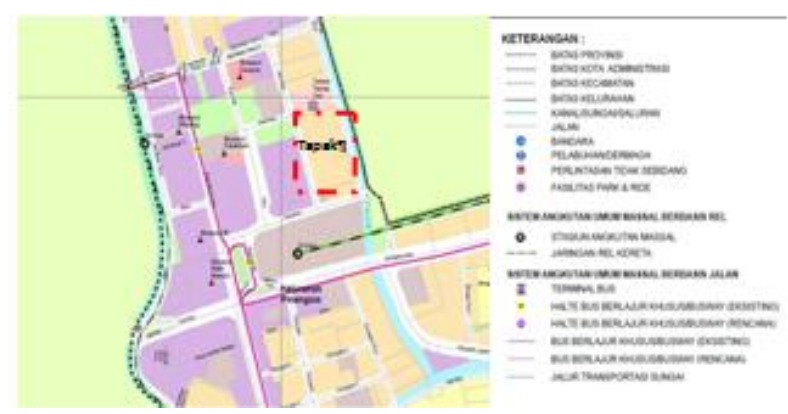

Gambar 3. Peta Transportasi disekitar tapak Sumber : LRK2014 
Untuk jarak yang ditempuh dari Bandara Internasional Soekarno Hatta ke lokasi tapak \pm 20 $\mathrm{km}$. Jika menggunakan kendaraan pribadi hanya dibutuhkan waktu sekitar \pm 30 menit untuk sampai lokasi tapak. Dan jika menggunakan kereta berkisar antara 80-100 menit. Angkutan umum yang melewati, busway, kereta api, mikrolet, KWK, kopami, kopaja, metromini, APTB. Tempat pemberhantian angkutan umum ini bejarak $500 \mathrm{~m}$ dari tapak sehingga lokasi proyek dapat dicapai dengan berjalan kaki. Para turis lokal dapat menggunakan transportasi umum untuk mencapai lokasi proyek, sehingga menjadikan proyek yang akan dibangun mudah untuk dicapai.

\section{Lokasi Tapak}

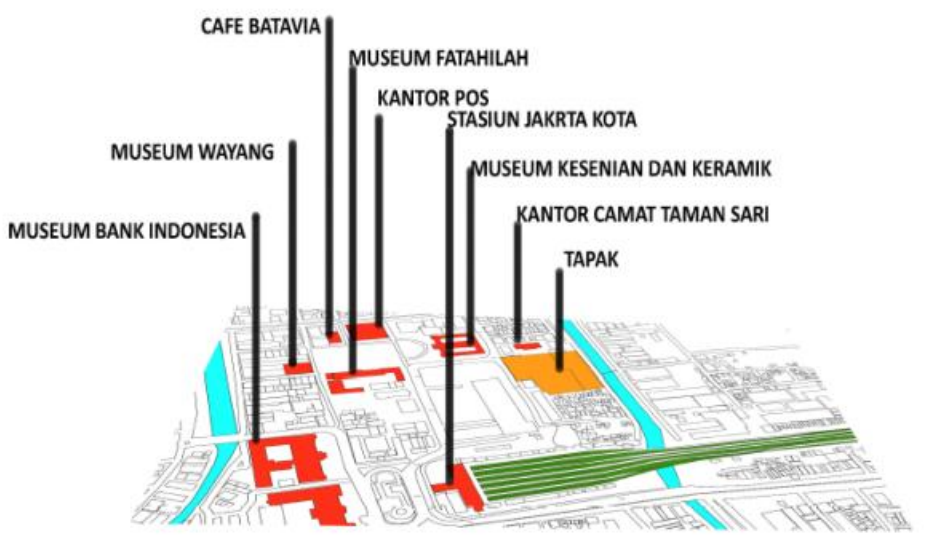

Gambar 4. Peta Kawasan Jakarta Barat

Sumber : Peta CAD 2014 yang telah diedit

Penambahan program pada kawasan disekitar Museum Fatahilah dibutuhkan untuk mewadahi komunitas serta memberikan tempat yang memenuhi standar untuk menampilkan pertunjukan seni teater. Selain itu komunitas juga dapat berperan dalam mengajar serta melatih anak-anak usia sekolah dasar maupun sekolah menengah atas yang ada di sekitar kawasan kota tua untuk mengedukasi dan melestarikan seni yang dibawakan oleh masingmasing komunitas.

Penambahan program dilakukan pada tapak yang letaknya berada di depan Wisma BNI Kemukus. Program yang diberikan diharapkan agar dapat menghidupkan daerah tersebut selama 24 jam serta dapat menarik wisatawan. Ketinggian bangunan yang ada di sekitar proyek yaitu sekitar 25-30 meter.

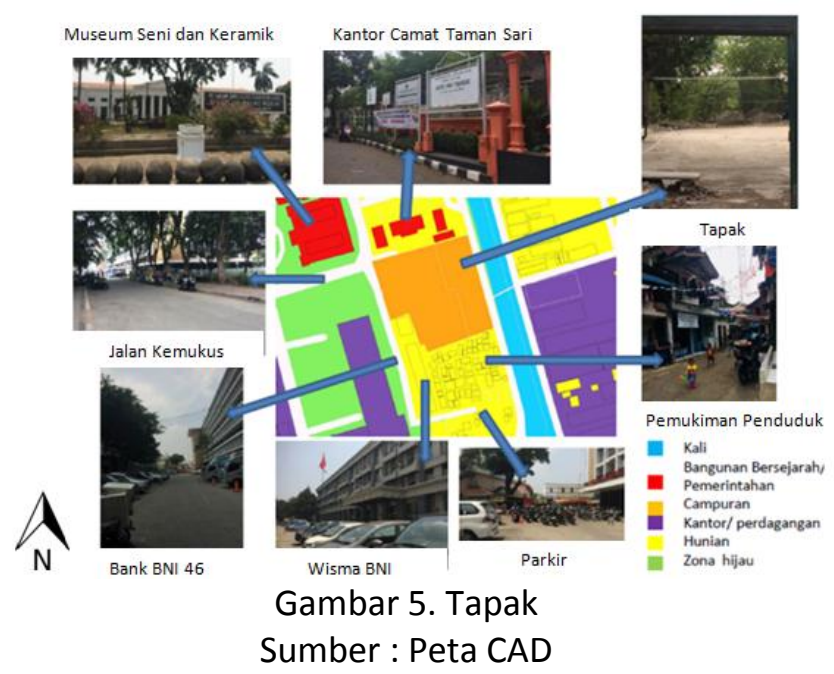


Tapak berada di jalan kota tua, Pinanggisan, RW 6, Taman Sari, Jakarta Barat. Tapak berbatasan dengan Wisma BNI Kemukus pada bagian selatan, pada bagian barat bersebelahan dengan BNI Corporate University, pada bagian utara bersebelahan dengan Kantor Camat Taman Sari, dan pada bagian timur bersebelahan dengan kali. Luas tapak 16.900 m2. KDB 70\%, KLB 3, KB 4, KDH 30, KTB 55.

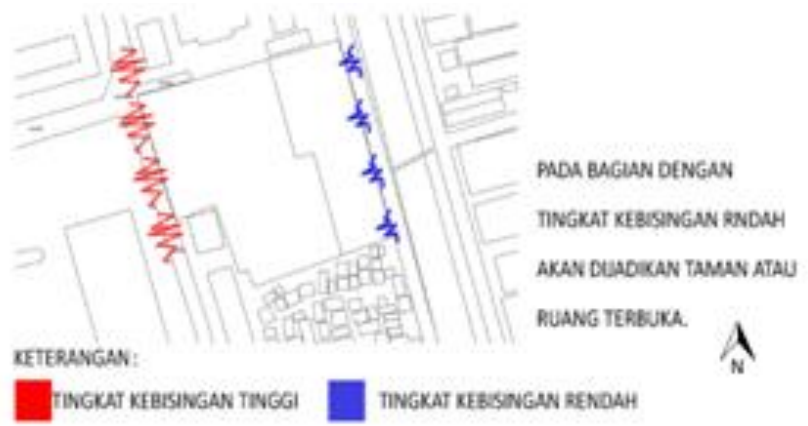

Gambar 6.. Pengamatan kepadatan kendaraan dan kebisingan Sumber : Peta CAD 2014

Pada gambar dapat dilihat bahwa pada bagian barat tapak kebisingan lebih tinggi sedangkan pada bagian timur yang bebatasan dengan kali kebisingan rendah. Pada desain yang akan dibuat pada bagian yang memiliki kebisingan tinggi akan diberikan pohon sebagai peredam suara ataupun bagian entrance di arahkan pada sisi selatan atau utara. Pada bagian yang memiliki kebisingan rendah dijadikan daerah service.

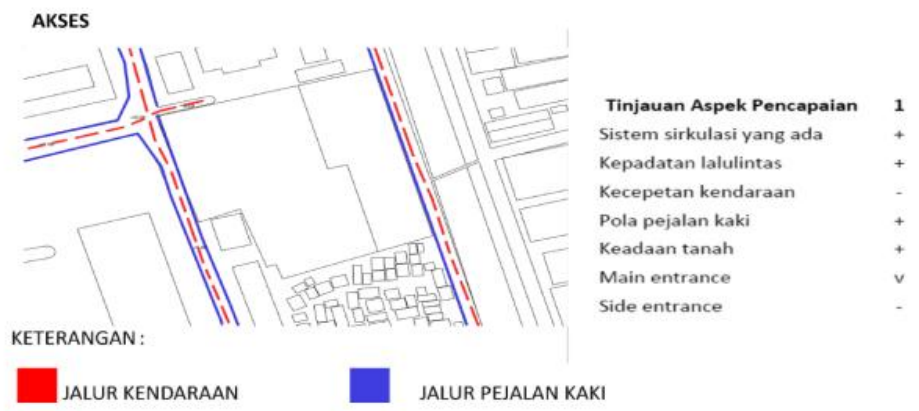

Gambar 7. Akses sekitar tapak Sumber : Peta CAD 2014

Berdasarkan tinjauan aspek pencapaian di atas, maka dapat disimpulkan bahwa akses untuk masuk ke tapak akan berada di sebelah barat.

\section{Program dan Fasilitas}

Proyek yang akan dibangun memiliki tujuan untuk memberikan informasi dan panduan wisata yang jelas di Indonesia bagi para wistawan lokal dan mancanegara. Serta memperkenalkan budaya, kuliner dan berbagai macam kerajinan tangan.

Sehingga untuk memenuhi tujuan proyek maka perlu menyediakan fasilitas-fasilitas sebagai berikut:

Ruang utama

- lobby atau hall,

- tiket box,

- lavatory penonton pria,

- lavatory penonton wanita,

- counter informasi,

- audiotorium atua ruang

- lobby pemain, 
- panggung,

- ruang briefing,

- ruang tunggu pemain,

- ruang pesiapan,

- ruang ganti pemain pria,

- lavatory pemain pria,

- ruang rias pria,

- ruang ganti pemain wanita,

- lavatory pemain wanita,

- ruang rias wanita,

- musholla,

- udang alat pentas,

- ruang crew,

- ruang panel listrik,

- ruang kontrol suara,

- ruang kontrol cahaya,

- ruang lampu sorot.

- ruang galeri.

Pendukung dan pelengkap

- kantor pengelola,

- kantor admin,

- ruang arsip,

- ruang sekretaris,

- ruang rapat

- kantin

- tenant

- toserba

- toko souvenir

- restaurant

- food court

- café

- ruang seminar

Servis

- toilet pria

- toilet wanita

- kitchen

- gudang

Luas ruang utama 12.992 , luas ruang pendukung dan pelengkap $2.784 \mathrm{~m} 2$, dan luas ruang servis sebesar $928 \mathrm{~m} 2$, sehingga total luas bangunan $18.560 \mathrm{~m} 2$. 


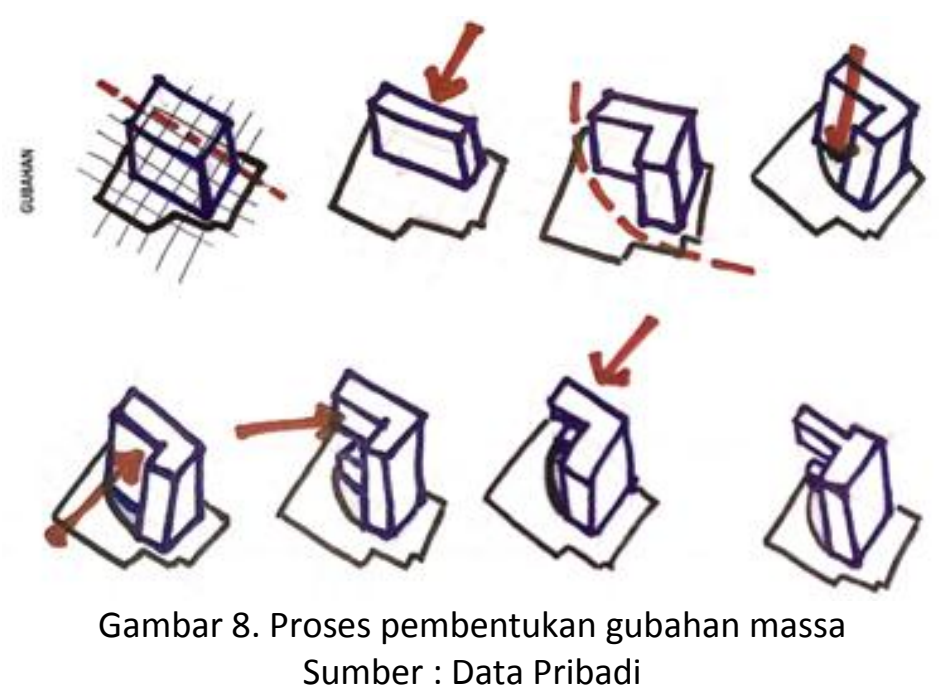

Pada proses pembentukan gubahan massa. Massa banguan yang memenuhi KLB di potong menjadi persegi panjang. Di tambahkan masa pada bagian selatan, masa yang ditambahkan berbentuk persegi panjang namun lebih kecil dari massa yang pertama. Lalu massa dipotong dibagian tengah depan, sehingga membentuk bukaan. Pada bagian barat, diberikan turunan yang bebentuk seperempat lingkaran yang akan di gunakan sebagai ruang komunal.

\section{KESIMPULAN}

Program yang diusulkan adalah Theater and tourist Information Center yang bertujuan untuk menyajikan keindahan Indonesia kepada para turis, serta memberikan kesempatan kepada para turis untuk merasakan secara langsung bagian dari tempat-tempat wisata di Indonesia. Informasi yang disajikan melalui media film, tari teater, musik, foto, aksesoris, dan makana khas dari beberapa daerah yang ada di Indonesia.



Gambar 9. Exploded Bangunan

Sumber : Data Pribadi

Banguan pada proyek ini menggunakan kaca sebagai kesan modern dan menggunakan garis vertikal pada pembagian lantai bangunan dan horizontal pada kolom sebagai unsur dari bangunan sekitarnya. Sertanya adanya modul-modul kaca yang memanjang memberikan kesan modern dan mengambil unsur bangunan sekitar. Sehingga konsep bangunan selaras dengan bangunan sekitarnya dengan menganut unsur modern. Dimana pada bangunan tua di sekitar tapak menggunakan dinding ya masif sedangkan bangunan yang dibangun pada tapak menggunakan dinding yang transparan. 
Tabel 2. Jam Oprasional

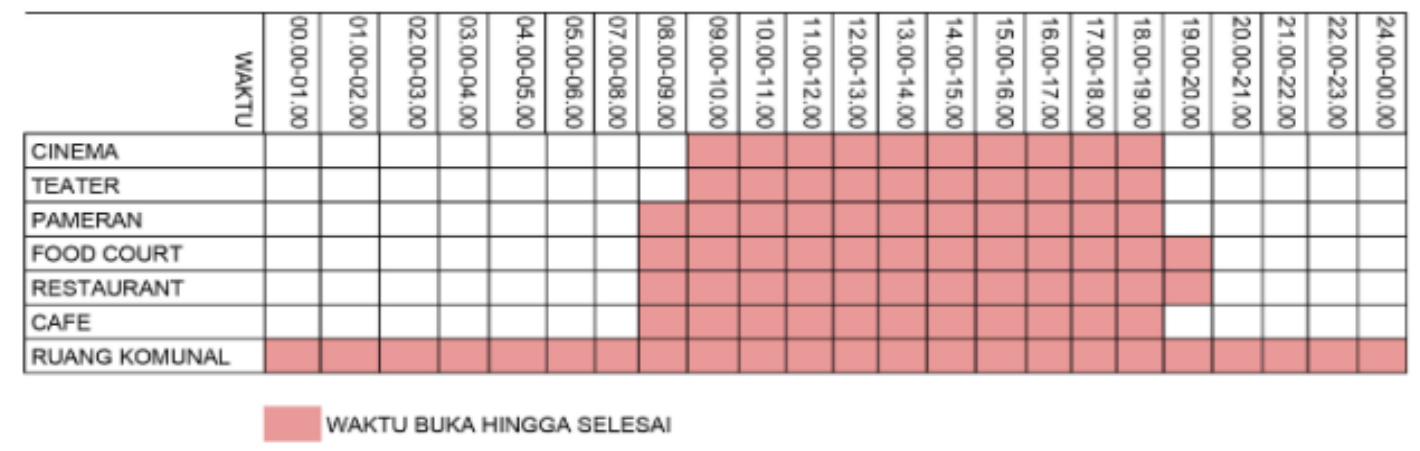

Sumber: Data Pribadi

Pengguna bangunan ini mencakup anak-anak hingga orang dewasa. Dengan jadwal buka senen- jumat dari pukul 09.00-20.00 dan pada hari sabtu dan minggu dari pukul 09.00-21.00 untuk bangunan utama sedangkan pada area ruang komunal buka 24 jam.

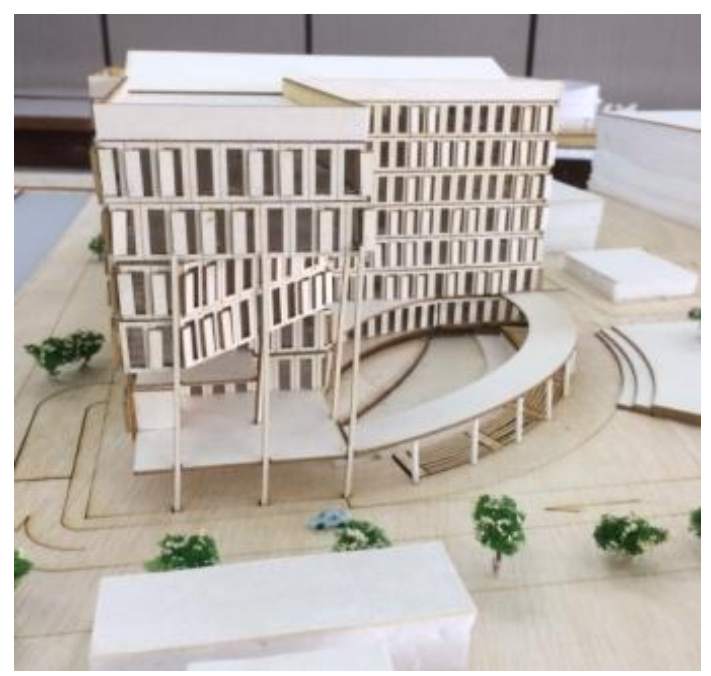

Gambar 10. Maket

Sumber : Data Pribadi

\section{REFERENSI}

Barron, Michael. (2010). Audiotorium Acoustic and Architectural Design: Spon Press

Specht, Jan. (2014). Architectural Tourism Building for Urban Travel Destinations: Srpringer Fachmedien Wiesbaden.

https://teadram.blogspot.com/2017/02/sejarah-teater-indonesia-sejarah-teater.html (diakses tanggal 5 Oktober 2018 pukul 12.00)

http://syafriadimoak.blogspot.com/2013/12/jenis-jenis-panggung.html (diakses tanggal 5 Oktober 2018 pukul 13.40)

https://www.theguardian.com/artanddesign/2017/oct/01/bilbao-effect-frank-gehry-

guggenheim-global-craze (diakses tanggal 5 Oktober 2018 pukul 14.10)

https://ilmuseni.com/seni-pertunjukan/pengertian-seni-pertunjukan-menurut-para-ahli

(diakses tanggal 5 Oktober 2018 pukul 14.40)

https://id.wikipedia.org/wiki/Kota_Tua_Jakarta (diakses tanggal 5 Oktober 2018 pukul 11.40) https://ilmuseni.com/seni-pertunjukan/pengertian-seni-teater (diakses tanggal 10 Oktober 2018 pukul 11.40)

https://www.scribd.com/document/363932030/Gedung-Pertunjukan (diakses tanggal 10

Oktober 2018 pukul 12.00) 